https://doi.org/10.15407/scine16.05.020

IEFYMENKO, T.

Academy of Financial Management, State Educational

and Scientific Establishment

38, Drugby Narodiv Blvd., Kyiv, 01014, Ukraine,

+380 44277 5115, afu@afu.kiev.ua

\title{
FISCAL REGULATION OF NATIONAL ECONOMIES' SUSTAINABLE GROWTH
}

Introduction. Even under the conditions of harsh coronacrisis load, modern fiscal policy in market economy states is aimed at regulation of distribution of resources between private and public sectors with the minimum impact of either inflation or deflation fluctuations on the producers' price index.

Problem Statement. The state's moves that mobilize market potential, should include the elements of tax and budgetary reforms, that are linked to the complex of actions that are aimed to halt the growth of money supply.

Purpose. To identify the main directions of a systemic governments' fiscal functions strengthening, primarily, in countering the destabilization threats in the presence of dynamic phenomena of globalization, crisisgenity and their further multiplication.

Materials and Methods. The methods of position-time situational analysis and synthesis have been used; the dynamics of statistical macroeconomic indicators (GDP) within the framework of various systematic model assessments of the tax reform impact have been compared.

Results. Both the positive and the negative experience of implementing programs for international financial institutions and governments of different countries aim at achieving the goals of full employment and sustainable development with the help of tax and budgetary means of demand management and established monetary leverages have been considered. Recommendations for strengthening of regulatory fiscal tools on Ukraine's socioeconomic system (SES) stability growth have been justified in the light of current trends of change management, especially against the background of COVID-19 pandemic.

Conclusions. Rational tax policy shall provide for the improvement of legislative mechanisms in combination with the formation and use of costs, stimulating the saving of resources with a view to their best practical use. Mandatory payments shall come from sources of business income rather than from capital, because the use of the latter for paying taxes is contrary to the interests of investors and the goals of sustainable reproduction.

Keywords: fiscal regulation, deglobalization, taxation, debt, savings, investment, and reforms.

The boundaries of financial globalization delineate the space of business activity of national economies through a set of monetary property contractual relations. According to experts, the current regulatory paradigm for comprehensive development provides

Citation: Iefymenko, T. Fiscal Regulation of National Economies' Sustainable Growth. Sci. innov. 2020. V. 16, no. 5. P. 20-35. https://doi.org/10.15407/scine16.05.020 
a "new context" for the interaction of economic agents [1]. The protection of domestic producers at the state level may be accompanied by the appearance of signs of general deglobalization, which in the future is likely to lead to certain restrictions on the movement of transnational capital, with all related consequences. In the $21^{\text {st }}$ century. the modern world will pass through a rather difficult period of transformations. Anti-crisis measures in each country should take into account the differences in fiscal, monetary, and social policies, as well as stability resources of the real and the financial sectors. Deficit-ridden national budgets that do not contain an institutional component of development become catalysts for the consumptive model of economy, escalate inflation and import growth, and worsen the current account balance. The equalized fiscal system is one of the main conditions for a sustainable reproduction. Both the overestimation and underestimation of the importance of the financial system and instruments of fiscal and monetary policy are equally dangerous for national economy and adequate living standards. Therefore, the protection of national interests in these areas guarantees the state's ability to effectively form, protect against excessive depreciation, and to rationally use financial resources for developing the socioeconomic sphere and servicing institutional commitments. Peculiarities of public management within the framework of modern global and national financial relations crucially depend on the chosen forms of taxation, as well as on the types, amounts, and methods of tax preferences. Historical world and domestic experience has shown that the global environment, against the background of accelerating overall financialization and the need to achieve the UN Sustainable Development Goals, will require harmonization of fiscal functions in government regulation based on the principles of justice, equality, neutrality at both macro and micro levels. This is especially important in the current unpredictable crisis associated with the COVID-19 pandemic.
The classic of global capitalism J. Soros rightly emphasized that the economy should be market one, while the state and the society should be social [2, p. 159]. Without solving social problems, economic development is hampered by dropping reproductive potential, narrowing the national market, and decreasing its role in the system of global competitive space [3]. An unexpected decline in Ukraine's economy in 2020, as well as an extremely unfavorable forecast for the medium term caused mainly by an adverse impact of quarantine restrictions because of the COVID-19 pandemic [4] require the development and implementation of unprecedented state anti-crisis measures, including fiscal ones. Many scholars are known to think that a fiscal program should result not only in the withdrawal of a certain part of income, but also in the solution of social problems. In particular, A. Wagner put forward a socio-political theory that taxes, along with the financial function, could be used for regulatory intervention in the turnover of newly created value so as to ensure compliance with the principles of justice for different segments of the population [5]. According to researchers [6-8], an efficient fiscal policy should focus on counteracting imbalances in national socio-economic systems. Therefore, to assess the fulfillment of resource revenue components of budgets at all levels and the further formation of sources of income, it is extremely important to constantly monitor the overall economic balance. It is implied that under the influence of external and internal risks, there are a growing threat of destabilization of market contracts and unforeseen fluctuations in the flow of goods and services. The conceptual foundations of general equilibrium analysis have led to the development of theoretical and empirical simulations that link the aspects of consumption and production. In the 1970s and 1980s, J. Wally and J. Chauvin, based on the applied model of the general equilibrium of the US economy for assessment of fiscal changes, showed differences in the impact of sales taxes imposed on either manufacturers or con- 
sumers, depending on varying structure of trade in certain goods, on international trade [7]. Undoubtedly, it is quite difficult to rely upon practical estimates obtained as a result of adopted forecasting standards. However, regular monitoring of the relationship between changes in taxes, tariffs, and competitiveness of national economies is essential for management decisions in the spheres of public finance and international trade in terms of economic development. Modern researchers have emphasized an extreme importance of such approaches to analyzing the impact of the dynamics of export sector quantitative indicators on wages and taxes [7, 8]. Thus, public policy should always focus on assessing the interplay between fiscal effects and economic situation, as taxes often pose unforeseen risks in the view of financial implications of distortions in investments and in the balance of labor supply and demand.

According to J.M. Keynes, the government shall influence the market in order to increase demand, because, in his opinion, overproduction trends have always been among the most important factors of economic crises [9]. He suggested to use the tools of fiscal policy as follows: if the economy declines because of a low aggregate demand, it is necessary to increase government expenditure and to reduce taxes, and, conversely, if the aggregate demand is too high, the government should cut expenditure while strengthening tax burden. Thus, in the opinion of J.M. Keynes, taxation as a component of the national fiscal environment can be used not only as a way to withdraw money from various areas of business to replenish the budget, but also as a tool to mobilize and to concentrate resources for comprehensive regulatory influence on market parameters, including the stability of economic growth [9].

To stabilize economic systems, in particular while implementing anti-inflationary measures, from the standpoint of neoclassical theory, it was proposed to combine the recommendations of monetarists on monetary regulation with such a conventional approach as granting businesses with fiscal relief [10]. The proponents of the theory of supply considered it necessary to provide support for involuntary mechanisms of reproduction in the framework of the freedom of private business [11, 12]. Opportunities for economic growth used to be considered in a functional relationship with the accumulation of capital resources: first, by means of internal resources obtained from capitalization of share of profit, and secondly, by means of borrowed funds.

The likely effects of capital gain taxation on the formation of a certain net income rate motivate owners to make decisions that affect the movement and distribution of assets. A. Harberger, M. Scholes, and M. Wolfson note that mandatory payments to the state from financial outcomes of corporations significantly affect their behavior reducing the net income of not only business beneficiaries, but also all capital owners [13 - 15]. Accordingly, assuming that in some sector of economy, in the process of capitalization of resources, there are fluctuations in the tax burden, the assets are likely to move to other areas of business activity, in any case, changing the profitability of manufacture and services. J. Slemrod and other researchers pay special attention to the distribution of income tax burden in the process of capital movements in international trade [16, 17]. The main factors influencing this indicator include: first, whether the country of taxation is an exporter or importer of capital; second, the level of risk and diversification of investment portfolios, including in terms of the foreign-to-domestic assets ratio and the rules of offsetting foreign payments to the budget against domestic tax liabilities (if taxes are paid in jurisdictions where tax rates are much lower than in the country where the value added is created); third, how the tax burden on labor is distributed depending on the residence of the employees. The issue of integration of monetary and budgetary policies given the unity of the Sustainable Development Goals of the country has been in the focus of many foreign and domestic scholars [18-27].

The new economic policy of the United States of America has confirmed the pessimistic assess- 
ments of well-known researchers [28] concerning the prospects of the global economy and world monetary and financial systems (WMFS). Among the main causes of its malfunction are the following ones:

- a privileged position of the dollar-centric model as a trigger of financial crises, information asymmetries, and diverse configurations of the global debt pyramid;

- systemic shortcomings in the regulation of the intermediary financial sector, which has led to the emergence and rapid deployment of trends in overconsumption, advanced growth of real income, cheap loans, and growing social inequality;

- mass involvement in global market relations, including the high-tech segment, of emerging market economies, when the created and operating institutions of economic innovation are often threatened by inertial components of the dominant model of financial stabilization, which violates the paradigm of economic growth.

"Tramponomics" has confirmed the need to further increase the efficiency of international regulatory institutions. First of all, it is a matter of directing program documents towards realizing the purposes of full employment and steady development by means of tax and budgetary tools of management of demand and the established levers of the international lending, and towards achieving a monetary balance of national BOPs (Balance of Payments). In addition, in order to ensure compliance with the principles of justice in the international relations of economic entities, it is necessary to rely on improved approaches to trade stimulation, including the application of customs tariffs. This is especially important given the introduction by the United States of additional fiscal burden in trade relations with the EU, Canada, and China. A clear illustration of such trends was the final document of the G20 summit in Hamburg (July 2017), in which there was no traditional requirement for the member states to counter protectionist measures. Relevant changes in the positions of governments because of the strong immigration crisis have been also reported in many Western European countries.

From the standpoint of economic agents, bearers of interests of international organizations, for example, in debt policy, it is necessary to get rid of significant amounts of unproductive, but necessary public expenditure, including in the field of life support. This means, in such cases there may be a political trilemma of the world economy and financial globalization [29-31], when the success of simultaneous implementation of democratic principles and progress of sovereign nations, along with civilization hyper-globalization, not always are confirmed by specific sustainable growth scenarios. In this context, the modern researchers have drawn attention to the problem of choosing the forms of regulatory government intervention in the market relations, in particular, while introducing the stabilization measures [32-34].

The purpose of this research is to substantiate the relevant recommendations for Ukraine concerning the government influence on increasing demand, creating conditions for stabilizing the balance between production growth and consumption through a sustainable development-oriented fiscal system and social benefits. Because of the unprecedented consequences of the world economy destabilization in 2020, the demand for systems of response to the risks of various global imbalances is getting higher at all management levels. Therefore, the main task is as follows: on the basis of world experience to develop and to implement national algorithms for combatting undesirable consequences, unforeseen sharp changes in macroeconomic indicators, employment rate, and exchange rates. Much attention is to be paid to the levers of regulation of the fiscal environment and the tax burden, which allow strengthening the competitiveness of all components of national SES based on its structural adaptation within both short-term and strategic prospects.

In the classical interpretation of modern researchers, globalization is an infinite number of sets of separate, often contradictory agreements 
in the space-time spheres of exchange of goods and services [35, 36]. Therefore, the level of involvement of a state in global processes is determined by the growth of localized supply chains of multinational corporations (MNCs) in individual jurisdictions and their coverage of global markets.

We share the opinion of the world expert community that further prospects for economic development require the creation and consistent implementation of a comprehensive program to reduce the gap in the population welfare between the so-called "golden billion" and "poor" countries that differ in income of different social strata [37]. Endless imbalances [38] within many processes of economic globalization in transition economies and emerging markets, including Ukraine, are accompanied by a wide range of unfavorable consequences:

- growing various risks for sustainable development of sovereign states, as a result of weakening competitiveness, factors of financial dependence, suppression of domestic markets, deepening social injustice, rising unemployment, etc.;

- increasing threats of environmental degradation, expansion of the shadow sector of the economy, the adverse impact of corruption, the emergence of institutional conflicts between the requirements of economic globalization and social, cultural, mental traditions of many countries;

- widening gap between poor and rich countries, as a result of economic globalization that multiplies world poverty.

Attempts to protect national producers at the government level are accompanied with the restoration of previously eliminated hidden trade barriers. The emergence of new and strengthening of existing supranational regulators makes it possible to continue harmonizing the regulation of the global movement of labor, as well as tangible and intangible assets. According to the IMF, in 2020 , the world economy may fall by $4.9 \%$. The experts have suggested that in the global scale, Ukraine's economy may be considered one of the most affected by the coronavirus because of fi- nancial destabilization, capital outflows, reduced exports, etc. [39].

In recent years, the tax burden in European economies has decreased, while government expenditure on investment projects and social benefits has increased, and measures have been introduced to support liquidity in the banking sector. In this regard, the formation of early warning systems for economic and financial fluctuations, the key parameters of which should be information support, transparency, and accountability, has become especially important for the "reset" of fiscal and monetary management mechanisms. Among the main factors determining the success of anticrisis regulation, the most important are the quality of fiscal institutions and macroeconomic policy, the structural characteristics of the economy, the exchange rate regime, the control of indicators of financial stability and fiscal consolidation. In particular, the role of the Council and the European Commission in monitoring the implementation of appropriate procedures has been strengthened. Pursuant to $\mathrm{Cl} .126$ of the Treaty on the Functioning of the European Union, the Member States shall avoid excessive government deficits, so the Commission shall monitor the development of the budgetary situation and of the stock of government debt in the Member States with a view to identifying gross errors. In particular, it shall examine compliance with budgetary discipline on the basis of the following two criteria:

(a) whether the ratio of the planned or actual government deficit to gross domestic product exceeds a reference value (3\% of GDP), unless:

- either the ratio has declined substantially and continuously and reached a level that comes close to the reference value,

- or, alternatively, the excess over the reference value is only exceptional and temporary and the ratio remains close to the reference value;

(b) whether the ratio of government debt to gross domestic product exceeds a reference value, unless the ratio is sufficiently diminishing and approaching the reference value at a satisfactory pace $(60 \%$ of GDP). 
Council Regulation No. 1177/2011 provides that the excess of a government deficit over the reference value shall be considered exceptional, when resulting from an unusual event outside the control of the Member State concerned and with a major impact on the financial position of general government, or when resulting from a severe economic downturn. The Regulation introduces a new benchmark for reducing the gross government debt: the ratio of the government debt to GDP shall be considered sufficiently diminishing and approaching the reference value at a satisfactory pace if the differential with respect to the reference value has decreased over the previous three years at an average rate of one twentieth per year as a benchmark, based on changes over the last three years. Also the rate of fine for noncompliance with these requirements has been established (it shall comprise a fixed component equal to $0,2 \%$ of GDP, and a variable component that depends on the government budget fulfillment) [40, p. 35, 39].

In order to strengthen integration in the economic and fiscal spheres in 2012, the EU Member States made the Treaty on Stability, Coordination, and Governance in the Economic and Monetary Union (hereinafter, the Treaty) [41]. It has not been signed by the two EU countries, UK and the Czech Republic. According to the Treaty, the structural government deficit should not exceed $0.5 \%$ of GDP at market prices. This norm on the maximum level of structural government deficit, as a rule, has been introduced into national legislations of the EU Member States. The Treaty provides for the creation of a centralized correction mechanism that is automatically used in the case of exceeding the limit of $0.5 \%$ of GDP for the structural deficit. The benchmark for gross public debt remains at $60 \%$ of GDP. Where the ratio of the general government debt to gross domestic product at market prices is significantly below $60 \%$ and where risks in terms of long-term sustainability of public finances are not high, the lower limit of the medium-term objective can reach a structural deficit of at most $1.0 \%$ of the gross domestic product at market prices (Article 3.1 of the Treaty).

The European Court has been given the right to impose fine on EU Member States for breach of the criteria set by the fiscal pact. According to Cl. 260 of the Treaty on the Functioning of the European Union, the Commission brings a case before the Court. The amount of fine may not exceed $0.1 \%$ of the GDP of a Contracting Party that breaches the benchmarks approved by the pact. The amounts imposed on a Contracting Party whose currency is the euro shall be payable to the European Stability Mechanism. In other cases, payments shall be made to the general budget of the European Union (Article 8.2 of the Treaty).

As of March 1, 2013, financial assistance under the European Stabilization Mechanism is provided subject to ratification of the Treaty and transposition of the rules of the fiscal pact into national law. This document contains updated regulatory indicators, as well as excessive deficit procedure (EDP). Factors influencing the choice of characteristics of the rate of achievement of certain results, in addition to the level of national debt, include the costs associated with population aging. The strengthening of fiscal rules, besides to the thresholds set stage by stage for a certain period, provides for the harmonization of accounting and statistics, as well as the right to review procedures and fines for non-compliance, including in the case of technological errors in developing and applying information criteria to thresholds of analytical data. According to IMF experts, in the crisis of 2020, the emerging markets have been affected by several adverse destabilizing factors. Due to a high probability of losing external debt financing opportunities, there will be a need for widespread use of debt restructuring procedures. Therefore, it is obvious that the existing rules of monitoring and debt settlement will require unprecedented adjustments [42].

The practice of financial management necessitates the adoption of government decisions on the sources of budget resources for development, economic modernization, implementation of struc- 
tural or social reforms, the consequences and effects of which are expected to manifest themselves in medium- or long-term period. In the context of the crisis that has erupted, it is extremely important to anticipate scenarios of long-term non-compliance with fiscal rules in conjunction with adjustments to macroeconomic forecasts.

In our opinion, the further progress of the institutional framework for the interaction of fiscal and monetary policies depends on the functional mechanisms of delegation of powers to the relevant management structures. Therefore, the role of coordinated norms and rules, which shape the managerial behavior of passive or active nature increases. In this context, it should be assumed that growing performance of central banks, as their independent status strengthens, can be seen as a challenge for fiscal policy makers in terms of their degree of autonomy. In our opinion, this statement is relevant, given the current state of affairs in our country. Monitoring or advisory activities of Independent Fiscal Institutions (IFIs) or councils that exist in certain countries are generally not accompanied with statutory established oversight functions. Today, the limits of regulatory powers of budget and fiscal structures are much narrower than the scope of competence of central banks, for example, in terms of supervision and law enforcement while setting interest rates. In the countries similar to Ukraine, economic reform programs should be based on studying the best world practice of delegation of rights and responsibilities, as well as their further harmonization in space and time. in order to ultimately obtain a synergistic effect from their interaction. This allows the relevant government agencies to address the problems related to inflation targeting and public debt control, while maximally keeping accountability, with a focus on unified, manageable, and transparent databases. Given that the national economy is below the potential level (a negative GDP gap will most likely be observed by 2021), in our opinion, a restrictive fiscal policy may become a limiting factor for economic growth in Ukraine. It should be borne in mind that the devaluation of the real effective exchange rate and the equalization of the trade balance have created the preconditions for the growth of government expenditure multiplier. The government debt can be reduced to $35 \%$ of GDP in 2030 if the budget deficit and the fiscal incentives increase, at least, until the end of the negative economic cycle. It should be noted that in Ukraine the general government deficit in 2020 will be equal to $8.2 \%$ of GDP (as compared with $2 \%$ of GDP, in 2019) and will significantly lag behind that in advanced economies. At the same time, in emerging markets, in 2020, the average deficit will be $10.6 \%$ of GDP and increase by 5.7 percent of GDP as compared with the previous year [39]. Given the current state of the national economy, it is necessary to stimulate the growth of demand and GDP, which creates space for greater use of monetary mechanisms of economic growth. In order to implement adequate measures and to avoid information asymmetry, it is extremely necessary to further standardize dimensions of fiscal environment. After all, the debt of previous years formed by previous governments exerts "pressure" on the fiscal policy of the current government. The latter shall respond simultaneously and appropriately to: the "fiscal past"; the current problems of the budget period; the medium-term goals and assessments of macroeconomic preconditions for their achievement; and the development factors and possible challenges in the long run. Given a significant dependence of the SES of Ukraine on the external situation, the coordinated monetary and fiscal components appear to be key tools of the government countercyclical strategy. Along with enhancing the National Bank's independence and focusing its actions on promoting financial sustainability and stable of the government anti-inflationary policy, strengthening the organizational framework of monetary and fiscal branches of economic power is the most important factor for successful reforms in Ukraine. In the case of excessively tight or lenient fiscal policy on government borrowing, monetary regulators will be forced to take compensatory measures in the medium term. 
Fierce debates over Brexit, Britain's withdrawal from the European Union, have shown that a strong form of integration can be seen by sovereign entities as devaluing the rights of nations because of many problems. This country with a fairly open economy has always advocated the preservation of general rules of the global trade order, when tariffs should be regulated against the background of the harmonization of standard rules. At the same time, the transition to a more protectionist system of contractual relations is likely to be difficult for the United Kingdom independent of the EU. Being specialized mainly in services, this country has always been an equal party to preferential trade agreements with the European Union and other partners. It is likely that in the future, given the relatively fragmented order of trade, the UK, as a medium-sized country, may face many problems related to the loss of lucrative contracts, since trade negotiations in the field of intangible operations may get more complicated.

Discussions on the division of powers between governments and EU structures have highlighted an excessive centralization of management functions by the Pan-European administration, including in the area of fiscal regulation. The changes in the foreign economic policy, as well as the fiscal reforms introduced at the end of 2017 in the United States, according to the Trumponomics Strategy (USA) [43], have led to a decrease in the global foreign direct investment (FDI) by $13 \%$ as compared with the previous year, in 2018 . The negative dynamics of this indicator for the third year in a row were caused mainly by a largescale repatriation of accumulated foreign income of U.S. multinational corporations. The reduction in the intensity of global FDI flows in the first half of 2018, mainly as a result of U.S. fiscal policy (40\% less than in the same period of 2017 ) was partially remedied in the second half of the year by increasing business activity [44].

In absolute terms, the global FDI flows have continued to decline in recent years reaching USD 1.3 trillion, in 2018 [45]. Cross-border mergers and acquisitions (M\&A) increased by $18 \%$, due to U.S. MNCs that had not been burdened with tax liabilities at the previous level any longer and used the liquidity potential of their foreign affiliates.

In 2019, FDI increased in advanced economies, as the fiscal reform in the United States has virtually exhausted its potential in terms of transferring resources to the national economic environment. The announced intentions to increase completely new investment projects in the future also strengthened the potential for FDI growth, despite the fact that their costs in 2018 increased by more than a third, as compared with a relatively low level of 2017. However, despite the above mentioned factors that are likely to have favorably affected the forecast of trends in the global FDI, in 2019, they amounted to USD 1.426 trillion, which was below the average for the last decade (however, it increased by $9.7 \%$ against the previous year [46]). According to the most optimistic scenario of the OECD forecast for 2020, the global FDI will fall by $30 \%$ [46]. In general, today we are witnessing the reformatting of the world labor division, when it is extremely difficult to predict the probability of the nature of "supply chain" failures. Because of the coronavirus pandemic, even successful corporations stopped manufacturing production of goods and services. Because of the border closure, countries need to move to the policy of self-sufficiency.

The interests of big business and capital in the context of adapting to new conditions of reproduction require strengthening the role of governments and intergovernmental unions in controlling the continuous accumulation of financial assets, increasing human and intellectual capital, and raising public wealth through fair taxation. The liberalization of global financial markets and the trend towards an asymmetric increase in external financing of national economies as compared with self-financing put many countries, especially transition economies, at a real threat of chronic debt dependence, global financial imbalance, and economic degradation. This situation has been partly caused by the growing trend of ca- 
pital outflows from emerging financial markets to stable and super-developed markets, such as the United States, the UK, Germany, Switzerland, and Japan [47].

Mandatory payments make it possible to concentrate taxpayer funds in national budget and to direct them to solving national economic problems, both industrial and social ones. Accordingly, sources of funding large R\&D, economic, and comprehensive targeted programs aiming at the development of industrial and social infrastructure are formed. In addition, by means of taxes, the government regulates consumption. In joint study by Urban-Brookings [48] and the J. Wharton Center of the University of Pennsylvania [49] described in the review published on the eve of the last presidential election in the United States (2016), the researchers and practitioners in public finance management made a comprehensive analysis of proposals for changes in the U.S. fiscal policy. While assessing the expected consequences of fiscal introductions, the authors used a short-term Keynesian model [50, 51] and an abstract approach to forecasting and modeling an exogenous economic growth with an emphasis on the dynamics of consumer behavior of individuals ${ }^{1}$. Their focus is Trump's reform program [52] in terms of fiscal introductions related to the simplification of administration and changes in the legislation concerning the fiscal relationship between government and business, which provides for:

- reducing tax rates, cancelling personal privileges;

- improving the methodology for calculating the taxable amount by increasing the standard deductions while limiting their specification, in particular, materially revising the rules that govern the procedure for referring interest on loans to expenses;

- stimulating rational choice and decision-making on new investments by corporation management.

${ }^{1}$ Penn Wharton Budget Model (PWBM).
Because of a significant reduction in tax burden on income of economic agents, the estimates have made it possible to assess the impact of introductions on the budget indicators.

First of all, an inevitable decline in federal revenues both in the first and in the second postreform decades has been projected. At the same time, expected behavioral reactions of taxpayers (how they perceive the cancellation of tax preferences and the enhancement of potential for savings and investments in the conditions of reducing marginal tax rates on income and capital gains) have been assessed. As a result, positive macroeconomic shifts will contribute to GDP growth in the short run. At the same time, the strengthening of trend towards growing federal debt is also possible. Accordingly, costs of servicing government borrowings are expected to increase, which, in turn, will restrain the pace of macroeconomic dynamics. Rising budget deficits are likely to lead to higher interest rates and the risk of squeezing investments out.

The researchers emphasize that the estimates are quite approximate. According to them, they will fluctuate significantly, as political reforms in the framework of the "Trumponomics" plan shall be clarified in terms of the degree of sensitivity of intentions of businesses and individuals in the field of savings, investment, and labor supply to changes in the government policy. Therefore, the impact on GDP may vary in both short and long term. Increasing tax revenues is ensured in several items of the new economic plan, and the intention to consolidate expenditure may nullify some or all adverse effects of the growing deficit [52].

Table shows the estimates of the impact of fiscal reforms on the GDP dynamics in the United States [53] and the comparison of actual, expected, and forecast data as of January 2020, August 2020, and 2016.

Table shows that GDP growth used by researchers in modeling the impact of U.S. fiscal system reforms in 2016 was estimated at +1.7 p.p. and +1.1 p.p. based on the Keynesian and the PWBM models, respectively (see lines 7, 9 of 


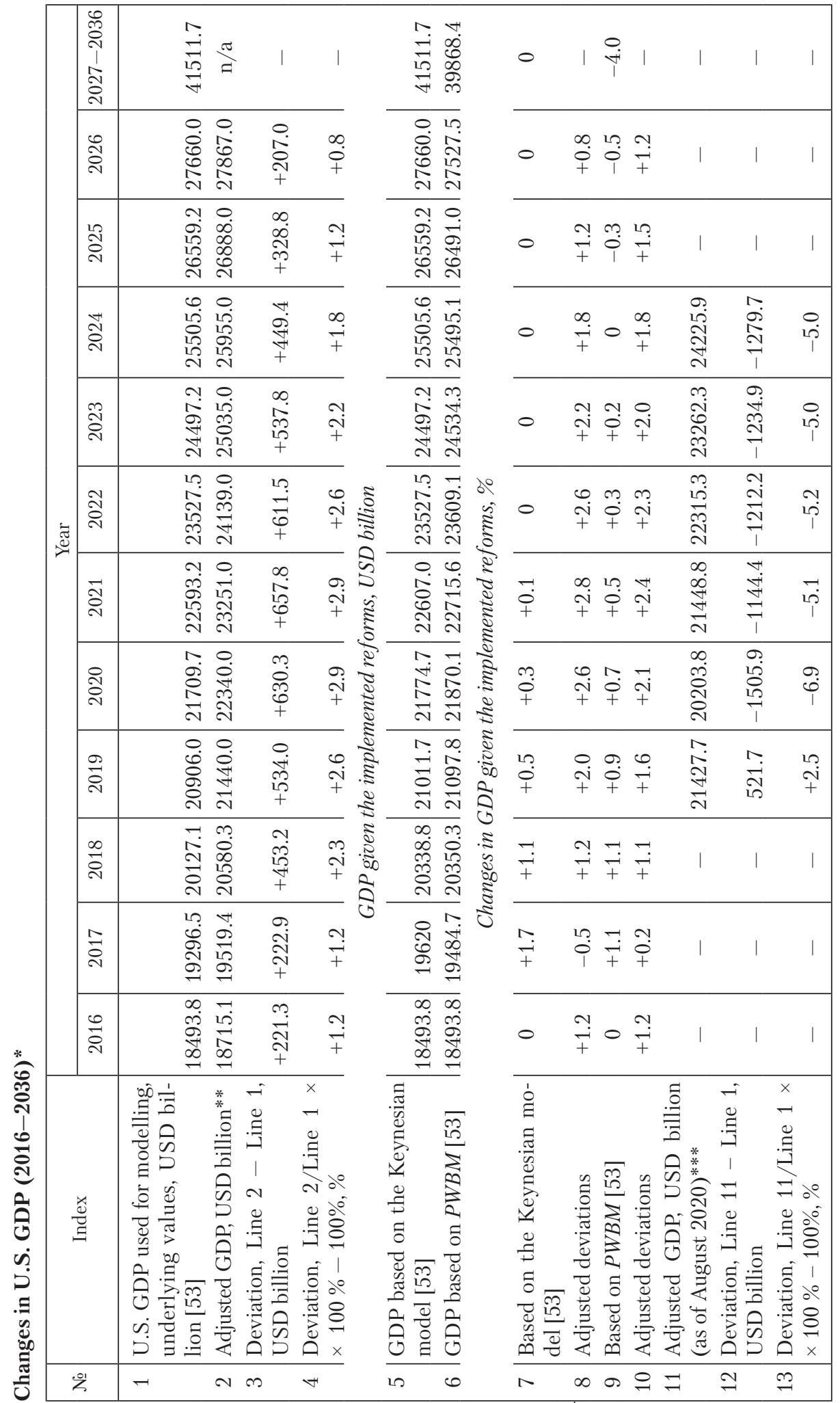

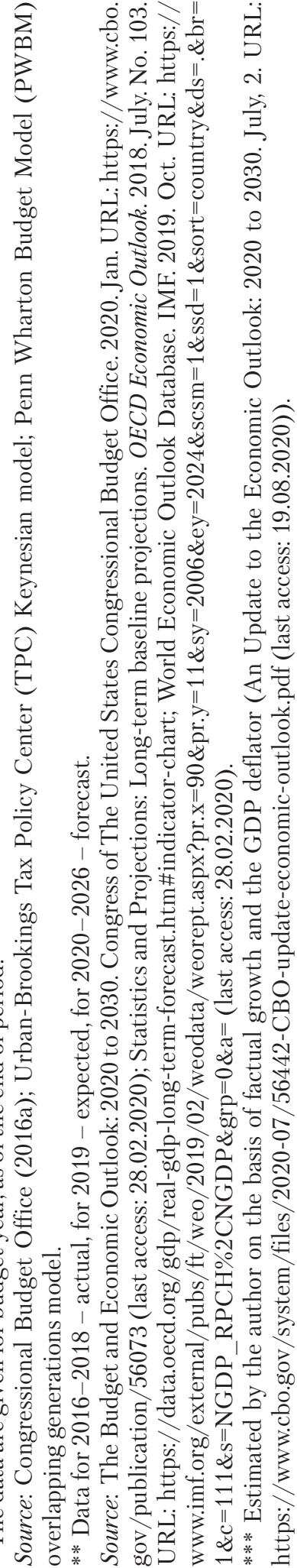

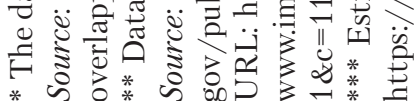


Table). The experts from the J. Wharton Center (see line 9 of Table) have suggested that changes in the fiscal legislation may have a negative effect in the form of reducing GDP to the projected value by $-0.3-0.5$ p.p. in $2025-2026$ and up to -4.0 p.p., in 2036. However, as of January 2020, the statistical data have confirmed the assumption of researchers that the macroeconomic effect of changes in the U.S. fiscal system is likely to exceed many expectations. Table shows that the adjusted GDP values have exceeded not only the initial forecast by $+0.8-2.9$ p.p. (see line 4 ), but also the estimates based on the Keynesian and the $P W B M$ models by $+0.8-2.6$ p.p. and $+0.2-2.4$ p.p., respectively. According to the data available at the beginning of 2020 , only in 2017 , there was recorded a negative ( -0.5 percentage points) deviation from the GDP forecast based on the Keynesian model (the actual value is USD 19.519.4 billion versus the forecast of USD 19.620 .0 billion).

Rapid changes in the world situation as well as in national economies have led to the fact that the data, which the world analytical community saw as quite plausible at the beginning of this year, were denied in the course of further events. Working on the article, the author had to change his own assumptions several times according to various forecast sources. As of August 2020, the revised estimated values of GDP (billion USD) are listed in line 11 of the Table. It is worth noting that these estimates are to some extent more pessimistic than those published in May 2020. Thus, if all forecasts from 2020 to 2024 predicted positive GDP growth, in August 2020 the situation is expected to deteriorate sharply ( -6.9 percentage points from estimates of 2016). The Table shows that in 2021-2024 we can predict moderate economic growth. However, it is possible that in autumn, when this publication will be issued, if the most pessimistic views on the second wave of the COVID-19 pandemic come true, the data given in lines 11-13 of the table may be irrelevant. The same applies to analytical data presented in the work on the basis of the source [39], as the next issue of this authoritative publication will come out in October 2020. This analysis contains many methodological innovations and, of course, from a scientific point of view, they will be used in the future. However, it should be noted that, given the US presidential election in autumn of 2020, it may be necessary to assess the impact of likely changes in tax reform strategy through new decisions on the socio-economic course of the United States and other countries.

It should be noted that the estimates of the impact of reforms on the tax burden distribution have been reduced by the majority of experts to the statement that households with the highest income will get the highest benefits in both absolute and relative terms.

In terms of simplifying fiscal administration, it is expected that the implementation of the updated Internal Revenue Code in the United States may have some advantages but, at the same time, may need to address many issues. For example, the significant increase in the standard deduction and the cancellation of privileges will ease the requirements for accounting and reporting, which consequently will significantly simplify fiscal administration procedures and balance the interests of the government and the taxpayers in terms of liability for tax accrual and payment. For many corporations, the possibility of cost classification depending on the choice of investment strategy, as well as the removal from the law of certain costs for the determination of taxable amount will also significantly facilitate accounting and tax administration procedures.

However, along with reducing the tax burden and simplifying the administration, some components of the reform are associated with certain difficulties. In particular, the new rules will require the adoption of fundamental decisions by high-income employees, given the institutionalization of the motivation to choose between the status of such an employee and the business owner. The corporations that prefer referring investment costs to expenses will lose the opportunity to use current payments for servicing loans in order to reduce the taxable amount. All this will compli- 
cate making investment decisions. In addition, incentives are created for the use of comprehensive financing mechanisms that focus investment and credit activities in the spatial or temporal dimension, given both the options for partnerships and the concentration of strategic initiatives within individual organizations. The proposed fiscal relief for child and dependent care will require parents and guardians to choose from a much larger number of ways to claim the right to reduce the tax burden through the application of new deduction rules and tax credits.

The experts have predicted that the fiscal reform introduced in the United States will have a significant impact on the global economy [54]. After all, the share of this country in the world economic space is about $1 / 5$.

The innovative corporate tax reform will also have a significant impact on the U.S. tax competitiveness, as many innovative fiscal provisions will help attract additional capital resources to the U.S. economy. The package of fiscal financing of measures for preventing bankruptcies and keeping the required amount of working capital in all countries is currently estimated at USD 11 trillion [39], where half is referred to the budget and tax expenditure. In addition, USD 5.6 trillion is assigned for providing government guarantees and loans and expanding the government share in the authorized capital of corporations. In G20, the fiscal measures "weigh" about $6 \%$ of GDP. In Ukraine, the Fund for Combatting COVID-19 is almost UAH 65 billion [55]. In the medium term, because of market fluctuations in quotations and demand for T-bills, the counteraction to the threat of crisis exacerbations should focus on supporting the national currency. In addition, in the conditions of growing budget deficit and foreign exchange outflow, the access to loans and their costs will remain problematic for Ukraine.

U.S. corporations will be able to transfer dividends from foreign affiliates to the parent company with virtually no tax. Because of a sharp decline in the corporate income tax rate, the introduction of new rules for the formation of the taxable amount, the corporations will be interested in specific changes in the debt policy. In addition, new tax regulations related to intangible income of foreign origin will stimulate research and innovation in the United States to promote their results abroad and will help reduce the placement of intellectual property in foreign jurisdictions.

Following the example of many countries, the United States is lowering corporate income tax rates and, in some cases, reducing tax breaks in order to attract more investments and to create new jobs. Lower rates and expansion of the taxable amount have been designed to counteract the international redistribution of profits through transfer pricing mechanisms and other financial solutions to save income [56].

Thus, in the future, humanity will be united by the goals of sustainable convergent and inclusive economic development. They have been described in many international documents that show that to ensure employment and to overcome impoverishment are among the main guidelines for sustainable growth in the context of the UN General Assembly resolution on the final joint document Transforming our world: the 2030 Agenda for Sustainable Development adopted in September 2015. To organize counteracting the destabilization potential associated with the unfair distribution of income requires a high level of coordination activity of the world community. Among the main tasks, there is the need to promote counterbalancing the migration policy, given the interests of both the host country and the country of origin, as well as standardization of tax assessment bases and minimizing the factors for reduction in tax liabilities and so on.

Ukraine has lost a significant resource for development because of shortcomings of both government and corporate management. This has had an extremely negative impact on the investments and upgrade of industry because of a low level of profit capitalization, capital outflow to offshore, inefficient depreciation policy, fiscal overburden of corporations, minimization of public 
investment and excessive consumption of the national budget, too limited resources, lack of transparency and accountability. which have led to a significant budget deficit. Along with the lack of regulation of methodological and practical approaches to the harmonization of fiscal and monetary components of the financial policy, all these factors have weakened the institutional capacity of the levers used for balancing the budget deficit and the total government debt.

Present-day monetary and financial relations are characterized by the highest level of globalization while maintaining the national form of organization of monetary and budgetary environment. Therefore, the network of structural units of MNCs, their financial and banking units should be coordinated in such a way as to use fiscal planning in compliance with the law, as well as to mobilize significant resources for innovative modernization of production with the help of high technology.

The existence of a system of institutional protection, counteracting the fiscal and monetary stability risks makes impossible any voluntary decisions and actions in the fiscal and monetary spheres. The level of their integration into the global financial market has a significant impact on the stability of SES. The potential for fair redistribution of resources is closely linked to the organization and implementation of transparent regulatory elements in governance. The systematized dissemination of the best practices of monetary and fiscal regulation should be coordinated with solving problems of universal resource conservation, development of the national economy towards scientific and technological progress with the commercialization of innovations. Transparent criteria for the economic feasibility of budget expenditure at all levels should include indicators of the efficient use of funds in compliance with the principle of social justice in their distribution.

The peculiarities of the introduction of supranational fiscal norms and rules and taxation, should be considered depending on the extent to which the SES is wholly or partially open. The examples from American economic practice have shown that President Barack Obama focused on such approaches to the fiscal burden to emphasize the importance of socializing the fiscal policy, whereas President Donald Trump has been pursuing a protectionist economic policy that is accompanied with increased consolidation of budget resources, concentration of public revenues and improvement of the efficiency of their use. At the same time, the possibilities for reducing and increasing the productivity of all expenditures, including the military ones, are under consideration.

The role of taxes constantly varies depending on the characteristics of SES, industry-related and other realities of development, without interfering with the processes of competitive pricing, the formation of savings and consumption, the distribution of time between leisure and work, etc. Even under changing conditions, taxation as a tool of government policy should not be "politicized", so it is always necessary to ensure a certain level of tax neutrality in relation to manufacturers and consumers, so as not to complicate economic decision-making. The importance of this task is constantly growing because of accelerating movement of capital and labor resources in the global world with a developed information, telecommunication, and transport infrastructure. It is increasingly important to take into consideration the growing mobility of taxpayers and new forms of doing business (e-commerce, Internet banking) and to create communications between tax administrations of different countries. After all, because of expanding opportunities for financial fraud, there is a need for international coordination of efforts in the fiscal sphere.

In order to ensure the stability of the financial system, the government policy of Ukraine in terms of promoting sustainable development of the country should form a single, well-balanced complex for the operation of managerial system and all components of the economic environment. At the same time, a sharp decline in economic activity in Ukraine and extremely unfavorable pro- 
spects against the background of the coincidence of uncertainties require change management to focus on reducing the tax burden, improving the regime of incentives for savings and investments, simplifying the administration of mandatory payments, and adhering to the principles of neutrality and partnership between government and business, etc. In this context, it is necessary to counteract the large-scale outflow of capital abroad, irrational use of financial resources in the economy, to prevent corrupt actions and misconduct in financial relations, and to neutralize deliberate actions of world economy agents shadow structures that neglect the established norms and rules within the economic and socio-political systems.

\section{REFERENCES}

1. World Economic Forum. (2015). World Economic Forum Annual Meeting 2015. The New Global Context (Davos-Klosters, Switzerland. January, 21-24). URL: http://www3.weforum.org/docs/WEF_AM15_Report.pdf (Last accessed: 03.07.2020).

2. Soros, G. (1999). The Crisis of Global Capitalism. Moscow: Infra-M [in Russian].

3. Bilorus, O. H. (2007). Global Competitive Space. Kyiv: KNEU [in Ukrainian].

4. National Bank of Ukraine. (2020, June 22). Comment of the National Bank on changes in real GDP in the first quarter of 2020. Retrieved from https://bank.gov.ua/ua/news/all/komentar-natsionalnogo-banku-schodo-zmini-realnogo-vvp-ui-kvartali-2020-roku (Last accessed: 03.07.2020) [in Ukrainian].

5. Wagner, A. (1900). Allgemeine und theoretische Volkswirtschaftslehre oder Sozial konomik. (Theoretische National-Oekonomie). Berlin: Als Manuskript gedruckt.

6. Goulder, L. H., Shoven, J. B., Whalley, J. (1982, June). Domestic Tax Policy and the Foreign Sector: the importance of alternative foreign sector formulations to results from a general equilibrium tax analysis model. NBER Working Paper, 919. doi: 10.3386/w0919.

7. Shoven, J. B., Whalley, J. (1992). Tax Comparisons. Chicago: National Bureau of Economic Research, University of Chicago Press. doi: 10.7208/chicago/9780226754826.001.0001.

8. Li, Ch., Whalley, J. (2012, March). Indirect Tax Initiatives and Global Rebalancing. NBER Working Paper, 17919. doi: $10.3386 / w 17919$.

9. Keynes, J. M. (2016). The General Theory of Employment, Interest, and Money. London: Macat International.

10. Mundell, R. A. (1965). The international monetary system: conflict and reform. Montreal: Canadian Trade Committee, Private Planning Association of Canada.

11. Smith, A. (2007). The Wealth of Nations. Moscow: Eksmo [in Russian].

12. Laffer, A. B., Seymour, J. P. (1979). The Economics of the tax revolt: A reader. New York: Harcourt Brace Jovanovich.

13. Harberger, A. C. (2006). Corporate Tax Incidence: Reflections on What is Known, Unknown, and Unknowable. Retrieved from http://www.econ.ucla.edu/harberger/ah-corptax4-06.pdf.

14. Scholes, M. S., Wolfson, M. A., Erickson, M. M., Hanlon, M. L., Maydew, E. L, \& Shevlin, T. J. (2014). Taxes \& Business Strategy (5th Ed). London: Pearson.

15. Brest, P., Gilson, R. J., \& Wolfson M. A. (2018). How Investors Can (and Can't) Create Social Value. European Corporate Governance Institute (ECGI) - Law Working Paper, 394, 1-33. doi: 10.2139/ssrn.3146718.

16. Slemrod, J. (1982, August). Tax Effects on the Allocation of Capital Among Sectors and Among Individuals: A Portfolio Approach. NBER Working Paper, 951. doi: 10.3386/w0951.

17. Shapiro, M. D., Slemrod, J. (2003, March). Consumer Response to Tax Rebates. American Economic Review, 93(1), 381396. doi: $10.1257 / 000282803321455368$.

18. Heyets, V. M. (2016). 25 years of transformational change. What's next? Economy and Forecasting, 2, 7-8. doi: 10.15407/ eip2016.02.005 [in Ukrainian].

19. Heyets, V. M. (2016). Ukrainian economy: key problems and prospects. Economy and Forecasting, 1, 7-22. doi: 10.15407/ eip2016.01.007 [in Ukrainian].

20. Hrytsenko, A. A. (2016). Ukraine's economy on the path to inclusive development. Economy and Forecasting, 2, 9-23. doi: 10.15407/eip2016.02.007 [in Ukrainian].

21. Hrytsenko, A. A. (Ed.). (2016). Institutional transformations of the socio-economic system of Ukraine. Kyiv: Institute of Economics and Forecasting of the National Academy of Sciences of Ukraine [in Ukrainian]. 
22. Danylyshyn, B. M. (2017, February 3). Monetarism and the Role of Central Banks: From Global Theories to Management Practice. Dzerkalo tyzhnia. URL: https://dt.ua/macrolevel/monetarizm-i-rol-centralnih-bankiv-vid-zagalnosvitovih-teoriy-do-ukrayinskoyi-praktiki-_.html (Last accessed: 03.07.2020) [in Ukrainian].

23. Korablin, S. O. (2016). The lagging growth model: economic factors and implications for Ukraine. Economy and Forecasting, 2, 74-85. doi: 10.15407/eip2016.02.071 [in Ukrainian].

24. Reinhart, C. M., Rogoff, K. S. (2011). This Time Is Different: Eight Centuries of Financial Folly. Princeton: Princeton University Press.

25. Soros, G. (2014). The Tragedy of the European Union. Disintegration or revival? Brussels.

26. Vague, R. (2014). The Next Economic Disaster. Why it's coming and how to avoid it. Philadelphia: University of Pennsylvania Press. doi: 10.9783/9780812291100.

27. Stiglitz, J. E. (2016). The Euro. How the common currency threatens the future of Europe. New York.

28. Temin, P., Vines, D. (2013). The leaderless economy: Why the world economic system fell apart and how to fix it. Princeton: Princeton University Press.

29. Galbraith, J. K. (1972). The New Industrial State. New York.

30. Galbraith, J. K. (1973). Economics and Public Purposes. Boston: Houghton Mifflin Company.

31. Galbraith, J. K. (1987). The End of Imperialism Era. Geneva.

32. Heyets V. M. (2020). The phenomenon of instability as a challenge to economic development. Kyiv: Akademperiodyka. doi: 10.15407/akademperiodyka.403.456 [in Ukrainian].

33. Niskanen, W. A. (2008). Reflections of a Political Economist: Selected Articles on Government Policies and Political Processes. Washington, D. C.: Cato Institute.

34. Tanzi, V. (2011). Government versus Markets: The Changing Economic Role of the State. New York: Cambridge University Press. doi: 10.1017/CBO9780511973154.

35. Rodrik, D. (2011). The globalization paradox: democracy and the future of the world economy. New York: WW Norton \& Company. doi: 10.1355/ae28-3k.

36. Levitt, T. (1983, May). The Globalization of Markets. Harvard Business Review. Retrieved from https://hbr.org/1983/05/ the-globalization-of-markets (Last accessed: 03.07.2020).

37. De la Peña McCook, K., Brand, K. (2001). Community indicators, genuine progress, and the golden billion. Reference \& User Services Quarterly, 40(4), 337-340.

38. James, H. (2017). Bretton Woods to Brexit. Finance \& Development, 54(3). URL: http://www.imf.org/external/pubs/ $\mathrm{ft} /$ fandd/2017/09/index.htm (Last accessed: 03.07.2020).

39. IMF. (2020, April). World Economic Outlook Database. Retrieved from https://www.imf.org/external/pubs/ft/weo/ 2020/01/weodata/index.aspx.

40. Council Regulation (EU) № 1177/2011 of 8 November 2011 amending Regulation (EC) № 1467/97 on speeding up and clarifying the implementation of the strengthening excessive deficit procedures. (2011). Official Journal of the European Union, L 306. URL: https://eur-lex.europa.eu/LexUriServ/LexUriServ.do?uri=OJ:L:2011:306:0033:0040:EN:PDF (Last accessed: 03.07.2020).

41. European Council. (2012). Treaty on Stability, Coordination and Governance in the Economic and Monetary Union. Brussels. Retrieved from https://www.consilium.europa.eu/media/20399/st00tscg26 en12.pdf (Last accessed: 03.07.2020).

42. IMF. (2020, April). Global Financial Stability Report: Markets in the Time of COVID-19. Retrieved from https://www.imf. org/en/Publications/GFSR/Issues/2020/04/14/global-financial-stability-report-april-2020 (Last accessed: 03.07.2020).

43. Faux, J. (2016. November 30). U.S. trade policy - time to start over (Report). URL: https://www.epi.org/publication/us-trade-policy-time-to-start-over/ (Last accessed: 03.07.2020).

44. United Nations Conference on Trade and Development (UNCTAD). (2019). World Investment Report 2019. Special Economic Zones. Geneva.

45. United Nations Conference on Trade and Development (UNCTAD). (2020). Foreign direct investment: Inward and outward flows and stock, annual. Retrieved from https://unctadstat.unctad.org/wds/TableViewer/tableView.aspx?ReportId=96740 (Last accessed: 03.07.2020).

46. OECD. (2020, April). Foreign Direct Investment Statistics: Data, Analysis and Forecasts. FDI in Figures. Retrieved from http://www.oecd.org/investment/FDI-in-Figures-April-2020.pdf (Last accessed: 03.07.2020).

47. Bilorus, O. H. (2015). Political world system of financial and economic globalization: new trends and patterns of global financial sector. Finance of Ukraine, 6, 7-14 [in Ukrainian].

48. Tax Policy Center. (n. d.). Engagement Policy. How the Urban-Brookings Tax Policy Center Engages with Presidential Campaigns and Evaluates Candidates' Tax Proposals. URL: http://election2016.taxpolicycenter.org/engagement-policy/ (Last accessed: 03.07.2020). 
49. Penn Wharton University of Pennsylvania. (n. d.). Budget Model. URL: https://budgetmodel.wharton.upenn.edu/ (Last accessed: 03.07.2020).

50. Page, B. R., Smetters, K. (2016, September 16). Dynamic Scoring of Tax Plans. URL: https://www.taxpolicycenter.org/ publications/dynamic-scoring-tax-plans (Last accessed: 03.07.2020).

51. Page, B. R., Smetters, K. (2017, April 5). Dynamic Analysis of Tax Plans: An Update. Retrieved from https://www.taxpolicycenter.org/publications/dynamic-analysis-tax-plans-update (Last accessed: 03.07.2020).

52. Congress of the United States of America. (n. d.). The Tax Cuts and Jobs Acts. URL: https://www.congress.gov/115/ bills/hr1/BILLS-115hr1enr.pdf (Last accessed: 03.07.2020).

53. Nunns, J. R., Burman, L. E., Rohaly, J., Rosenberg, J. (2016, October 16). An analysis of Donald Trusp's Revised Tax Plan. URL: https://www.taxpolicycenter.org/publications/analysis-donald-trumps-revised-tax-plan/media (Last accessed: 03.07.2020).

54. Mintz, J. (2018). Global Implications of U.S. Tax Reform. ifo Schnelldienst, 71 (7), 22-35. URL: https://www.ifo.de/ DocDL/sd-2018-07-mintz-us-tax-reform-2018-04-12.pdf (Last accessed: 03.07.2020).

55. UNN. (2020, June 19). Marchenko reported to the Verkhovna Rada on the use of funds from the fund to combat COVID-19. Retrieved from https://www.unn.com.ua/uk/news/1875928-marchenko-prozvituv-u-vr-pro-vikoristannya-koshtiv-izfondu-po-borotbi-z-covid-19 (Last accessed: 03.07.2020) [in Ukrainian].

56. Mintz, J., Weichenrieder, A. J. (2010, January). The Indirect Side of Direct Investment: Multinational Company Finance and Taxation. doi: 10.7551/mitpress/9780262014496.001.0001.

Received 02.03.20

Revised 24.04.20

Accepted 18.05.20

\section{T.I. Єфименко}

Державна навчально-наукова установа «Академія фінансового управління»,

бульв. Дружби народів, 38, Київ, 01014, Україна,

+380 44277 5115, afu@afu.kiev.ua

\section{ФІСКАЛЬНЕ РЕГУЛЮВАННЯ СТІЙКОГО}

\section{НАЦІОНАЛЬНОГО ЕКОНОМІЧНОГО ЗРОСТАННЯ}

Вступ. Сучасну фіскальну політику в країнах з ринковою економікою, навіть за умови обтяження коронакризою, спрямовано на регулювання розподілу ресурсів між приватним і державним секторами з мінімальним впливом інфляційних чи дефл яційних коливань на індекс цін виробників.

Проблематика. Дії держави, які мобілізують потенціал ринку, повинні охоплювати елементи податково-бюджетного реформування, пов'язані з комплексом цілеспрямованих заходів щодо зниження темпів зростання грошової маси.

Мета. Визначення основних напрямів системного посилення фіскальних функцій органів виконавчої влади, насамперед у протидії загрозам дестабілізації за наявності динамічних явищ глобалізації, кризогенності та їх подальшої мультиплікаціі.

Матеріали і методи. Використано методи просторово-часового ситуаційного аналізу та синтезу, а також порівняння динаміки статистичних макроекономічних показників (ВВП) у межах різних системних модельних оцінок впливу податкового реформування.

Результати. Розглянуто як позитивний, так і негативний досвід упровадження програм міжнародних фінансових інституцій та урядів різних держав, спрямованих на досягнення повної зайнятості працездатного населення й стійкого розвитку економіки за допомогою податково-бюджетних засобів управління попитом та усталених грошово-кредитних підойм. Обгрунтовано рекомендації щодо вдосконалення регуляторних фіскальних важелів зростання стійкості соціально-економічної системи України з урахуванням сучасних тенденцій управління змінами, зокрема на тлі пандемії COVID-19.

Висновки. Раціональну податкову політику слід орієнтувати на вдосконалення законодавчих механізмів у поєднанні з формуванням та розподілом видатків, стимулюванням збереження ресурсів із метою їх більш прийнятного практичного використання. Обов'язкові платежі мають сплачуватися з джерел доходів суб'єктів господарювання та не повинні стосуватися капіталу, бо спрямування останнього на сплату податків суперечить інтересам інвесторів та цілям стійкого відтворення.

Ключові слова: фіскальне регулювання, деглобалізація, оподаткування, борг, заощадження, інвестування, реформи. 